\title{
Rok 1336 w procesie przemian ustrojowo-prawnych Śląska
}

Niespodziewana śmierć księcia wrocławskiego Henryka VI Dobrego w dniu 24 listopada 1335 r. spowodowała, że, zgodnie z umową zawartą 6 kwietnia 1327 r., jego następcą w Księstwie Wrocławskim został król Czech Jan Luksemburski. Oznaczało to kres faktycznej dwuwładzy księcia i króla oraz zmianę ustroju politycznego księstwa. Przestał w nim panować przyrodzony książę z polskiej dynastii Piastów i w związku z tym stało się ono dziedzicznym księstwem króla i Korony Czeskiej, w którym odtąd panowali kolejni królowie Czech, nieprzerwanie aż do $1742 \mathrm{r}$. Uwagę zwraca fakt, że nie miało to wpływu na jego tytulaturę, w której nie pojawił się tytuł księcia wrocławskiego. We Wrocławiu Jan Luksemburski zjawił się dopiero w styczniu 1337 r., natomiast z jego polecenia przybył do tego miasta już w grudniu 1335 r. jego pierworodny syn, margrabia morawski Karol, późniejszy cesarz Karol IV. Pierwszym spektakularnym rezultatem tego pobytu było utworzenie urzędu starosty wrocławskiego. W styczniu 1336 r. jest już potwierdzony źródłowo pierwszy starosta mianowany przez Jana (capitaneus terre Wratislaviensis deputatus per serenissimum principem dominum regem Boemie et comitem Luceburgensem) ${ }^{1}$.

Urząd starościński w dziejach Księstwa Wrocławskiego nie był nowością. Zaistniał on po śmierci Henryka V legnickiego (1296 r.) w związku z rządami

${ }^{1}$ Pierwszy dokument pochodzi z 24 stycznia 1336 r. Regesten zur schlesischen Geschichte. 1334-1337. In: Codex Diplomaticus Silesiae [dalej: CDS], T. 22. Wyd. K. Wutke. Breslau 1923, nr 5554 [dalej: RS]. Wydarzenia polityczne z tego okresu przedstawił J. Dąbrowski: Dzieje polityczne Śląska w latach 1290-1402. W: Historia Ślaska od najdawniejszych czasów do roku 1400. Red. S. Kutrzeba. Kraków 1933. Por. Historia Śląska. T. 1: Do roku 1763. Cz. 1: Do połowy XIV w. Red. K. Maleczyński. Wrocław 1960, s. 562. 
opiekuńczymi (tutorat) sprawowanymi z powodu małoletniości jego synów (Bolesława, Henryka i Władysława) przez innych książąt śląskich i króla czeskie$\mathrm{go}^{2}$. W latach 1296-1301 Bolko I jaworsko-świdnicki używał tytułu opiekuna ziemi wrocławskiej (tutor terre Wratislaviensis) albo opiekuna Wrocławia (tutor Wratislavie) ${ }^{3}$. Po śmierci Bolka I (1301 r.) ich opiekunem zostali kolejno biskupi wrocławscy (Jan Romka i Henryk z Wierzbna), a następnie w latach 1303-1305 król czeski Wacław II, który swój tutorat sprawował za pośrednictwem starosty Benesza $^{4}$, a następnie biskupa wrocławskiego Henryka z Wierzbna ${ }^{5}$.

Na zjeździe książęcym we Wrocławiu w dniu 6 kwietnia 1327 r. Jan, tytułujący się królem Czech i Polski oraz hrabią Luksemburga, potwierdził mieszczanom Wrocławia oraz mieszkańcom i feudałom ziemi wrocławskiej wszystkie dotychczasowe prawa i wolności uzyskane od książąt Śląska i panów Wrocławia ${ }^{6}$. Król zobowiązał się ponadto do mianowania starosty $\mathrm{z}$ określonym rocznym wynagrodzeniem, który będzie strzegł mieszkańców ziemi wrocławskiej przed zasługującymi na potępienie szkodami. Mógł nim zostać tylko godny ziemianin tej ziemi. Być może w nawiązaniu do tego przywileju król mianował takiego starostę jeszcze za życia księcia Henryka VI. Przypuszczenie to potwierdza dokument z dnia 23 lutego 1330 r. wystawiony we Wrocławiu przez Henryka Haugwitza, tytułującego się „starostą Korony Czech i miasta Wrocławia”. W dokumencie wydanym przez króla czeskiego w Kłodzku 19 października 1331 r., dotyczącym wsi Radomierzyce w Księstwie Wrocławskim, występuje officiatus terre et districtus Wratislaviensis, ale pod tą nazwą krył się zapewne wójt ziemski a nie starosta ${ }^{8}$.

Po śmierci Bolka I rządy opiekuńcze w Księstwie Świdnickim przejął margrabia brandenburski jako „opiekun Śląska” (tutor Slezie), ale zastępował go starosta, Herman de Barboy tytułujący się „starostą Sląska” (capitaneus Sle$z i e)^{9}$. Tytulatura ta sugeruje aspiracje do objęcia rządami opiekuńczymi całe-

${ }^{2}$ Genealogiczne wiadomości dotyczące książąt śląskich: J. Jasiński: Rodowód Piatów ślaskich. T. 1-3. Wrocław 1973-1977.

${ }^{3}$ Urkunden des Klosters Kamenz. Hrsg. P. Pfotenhauer. Breslau 1881, CDS X, s. 50$55, \mathrm{nr} 45,67,73$.

${ }^{4}$ Wydatki miasta Wrocławia z 1304 r. za rok poprzedni. Henricus Pauper. Rechnungen der Stadt Breslau von 1299-1358, nebst zwei Rationarien von 1385 und 1387, dem Liber Imperatprois vom Jahre 1377 und den ältesten Breslauer Statutem. In: CDS, Vol 3. Hrsg. C. Grünhagen. Breslau 1860, s. 13. Benesz jako starosta króla sprawującego rządy opiekuńcze nad książętami wrocławskimi pobrał na jego rzecz 68 marek. Zob. RS 2773.

5 Starostą wrocławskim tytułował się w dokumencie z 26 maja 1305 r., zamieszczonym w najstarszym kopiarzu klasztoru św. Klary we Wrocławiu z XIV w. Zob. RS 2844.

${ }^{6}$ Pełny tekst Lehns=und Besitzurkunden Schlesiens und seiner einzelnen Fürstenthümer im Mittelalter. Hrsg. C. Grünhagen, H. Margraf. Teil 1, Nr. 8. Leipzig 1881 [dalej: GM I].

${ }^{7}$ Niedatowany transumpt rady miejskiej Wrocławia. Zob. RS 4918.

${ }^{8}$ RS 5059.

${ }_{9}$ Urkunden des Klosters Kamenz..., s. 56-58, 65, nr 76, 78, 79, 89 (1302-1310). 
go ówczesnego Śląska, łącznie z Wrocławiem. W 1328 r. Bolko II świdnicki zapewnił mieszczan świdnickich, że bez zgody swoich wasali oraz mieszczan Świdnicy nie ustanowi w swojej ziemi żadnego opiekuna i gubernatora (tutor seu gubernator $)^{10}$. O urzędzie starosty biskupstwa wrocławskiego dowiadujemy się w 1330 r. ${ }^{11}$. W latach 1331-1332 o opiekunie, staroście, względnie kasztelanie, słyszymy w odniesieniu do Głogowa, łącznie z gwarancjami udzielanymi mieszczanom tego miasta przez opiekuna i owdowiałą księżną, dotyczącymi ich prawa przyzwalania na takie nominacje ${ }^{12}$. Starostwo wrocławskie nie było zatem pierwszym, jakie pojawiło się na Śląsku, ale na pewno najbardziej prestiżowym i ważnym ze względu na rolę Wrocławia jako politycznego centrum całego środkowego Nadodrza. Stało się ponadto wzorcem dla innych starostw w dziedzicznych księstwach Korony Czech na Śląsku, zwłaszcza w Księstwie Świdnicko-Jaworskim, a później Opolsko-Raciborskim, a nawet w księstwach lennych. Urząd starosty ziemskiego w tym księstwie funkcjonował odtąd, z krótkimi przerwami, do $1741 \mathrm{r}^{13}$.

Już u schyłku XIII w. (w 1290 r.) na obsadę tronu książęcego w Księstwie Wrocławskim wywarły decydujący wpływ jego polityczne stany, szlachta i miasto Wrocław, zatem osoba opiekuna i starosty też wymagały uzyskania ich akceptacji. Stąd też grudniowemu pobytowi Karola we Wrocławiu musiało towarzyszyć zwołanie zjazdu ziemian z udziałem Wrocławia, czyli sejmiku ziemskiego księstwa, w celu przygotowania uroczystości pogrzebowych Henryka VI oraz złożenia przysięgi wierności i podległości królowi, reprezentowanemu przez jego sukcesora. Niewątpliwie kluczową kwestią, w związku z tylko okazjonalnymi pobytami we Wrocławiu króla i jego następcy, było utworzenie i personalna obsada urzędu starościńskiego. Osoba kandydata na ten urząd mogła budzić kontrowersje, zwłaszcza w przypadku arbitralnej decyzji monarchy nieuwzględniającej woli poddanych. Nie wiadomo, czy piastuna tego urzędu zaproponował król albo jego syn, czy zgromadzone stany, ale znana jest osoba, której go powierzono. Był nim Konrad z Borsnicz, tytułujący się starostą ziemi wrocławskiej albo krócej: starostą ziemskim. Zastanawia w tej tytulaturze unikanie oficjalnej nazwy księstwa. Konrad Borsnicz był członkiem rodziny Borschwitzów, wywodzących się najprawdopodobniej z okolic Miśni, ale osiadłych na Śląsku co najmniej w latach osiemdziesiątych XIII w., a więc przebywających tutaj już około 50 lat $^{14}$. Spotykamy ich już w tym czasie w otoczeniu Henryka IV Probusa i Henryka V Grubego jako piastunów wy-

${ }^{10} \mathrm{RS} 4775$.

${ }^{11}$ RS 4957.

12 RS 5004a, 5005, 5051, 5156.

13 Ostatnim był Otto Wenzel Reichsgraf von Nostitz und Reineck (1727-1741). G. Bobertag: Die Gerichte und Gerichtsbücher des Fürstenthums Breslau. „Zeitschrift des Vereins für Geschichte und Alterthum Schlesiens" [dalej: ZVGS] 1866, Bd. 7, s. 103-175.

${ }_{14}$ T. Jurek: Obce rycerstwo na Ślasku do połowy XIV wieku. Poznań 1998, s. 207-209. 
sokich urzędów (podmarszałek, marszałek). Brat Konrada, Herman, w 1332 r. był sędzią dworskim we Wrocławiu i zmarł w tym samym roku co Henryk V Dobry. Zapewne miało to wpływ na nominację Konrada na najwyższy odtąd urząd monarszy w księstwie. Pozycję starosty podkreślała nowa pieczęć, będąca oficjalną pieczęcią Księstwa Wrocławskiego, pozostającą w dyspozycji piastuna urzędu starościńskiego. Posiadała ona wizerunek tarczy podzielonej na cztery pola, w których znajdował się czeski lew i śląski orzeł oraz charakterystyczny owalnie usytuowany napis: [S. RE]GIS BOEMIE IN DUCATU WRATISLAVIEN. AD HEREDITATES ET C[AUSAS $]^{15}$. Podkreślał on, że była to pieczęć króla Czech w Księstwie Wrocławskim do dziedzictw i spraw, czyli własności dziedzicznej i spraw prawnych. Król nie uważał się w niej zatem za księcia wrocławskiego. W swojej tytulaturze starosta też odwoływał się tylko do pełnomocnictwa udzielonego mu przez króla a nie księcia wrocławskiego albo króla w roli księcia wrocławskiego. Było to zatem starostwo królewskie w księstwie. Wśród świadków wydawanych przez starostę dokumentów spotykamy innych przedstawicieli rodu Borsniczów: Ottona i Jana. Uwagę zwraca fakt zmiany osoby starosty już na początku kolejnego roku. Pierwszy dokładnie datowany dokument nowego piastuna tego urzędu (Heinrich von Hugowicz) pochodzi z 20 stycznia $1337 \mathrm{r}^{16}$. Jest to najpewniej ta sama osoba, która z tytułem starościńskim w odniesieniu do miasta Wrocławia pojawiła się w 1330 r., co być może oznacza, że bardziej odpowiadała królowi niż powołany w grudniu $1335 \mathrm{r}$. Borsnicz. Rodzina Hugewiczów (Haugwitzów) wywodziła się również z okolic Miśni i pojawiła się na Śląsku też w latach osiemdziesiątych XIII w. ${ }^{17}$. Już na początku XIII w. odgrywali dużą rolę na dworach książąt głogowskich, świdnickich i wrocławskich. Henryk pełnił urząd starosty wrocławskiego do $1339 \mathrm{r}$. W okresie sprawowania urzędu starosty ziemskiego przez Borsnicza założono księgi przywilejów dla Księstwa Wrocławskiego ${ }^{18}$. Dotychczasowy pisarz (Lutko von Culpe), który u schyłku panowania Henryka VI tytułował się książęcym pisarzem dworskim już w dokumencie z 24 stycznia 1336 r. występuje jako pisarz ziemi wrocławskiej ${ }^{19}$. Funkcjonował nadal wrocławski sędzia dworski (iudex curiae, Hofrichter), występujący w źródłach od początku XIII w. (1202), chociaż dworu książęcego już nie było, a dwór królewski tu nie powstał.

Nic nie wiadomo o koniecznej instalacji pierwszego starosty wrocławskiego na sejmiku księstwa ani o formalnym akcie nominacyjnym i zakresie udzielonego mu pełnomocnictwa w formie ustnej albo pisemnej (instrukcja). Pewnych infor-

15 RS 5589; APWr., Rep. 58: Klasztor Dominikanek(/) św. Katarzyny we Wrocławiu, nr 21; H. Wendt: Das Siegel der kgl. Landeshauptmannschaft im Fürstenthum Breslau. ZVGS 1899, s. 407-409.

${ }^{16}$ RS 5818.

17 T. Jurek: Obce rycerstwo na Śląsku..., s. 233-235.

${ }^{18}$ Wzmianka w najstarszej wrocławskiej księdze ziemskiej. Zob. RS 5538.

19 RS 5554. 
macji na ten temat dostarczają jednak licznie wystawiane przez niego w $1336 \mathrm{r}$. dokumenty. W przeważającej części dotyczyły potwierdzania $\mathrm{w}$ imieniu króla różnych czynności prawnych dokonywanych przez ziemian i mieszczan, najczęściej rozporządzeń majątkowych ${ }^{20}$. Tylko jeden dokument dotyczył okresowego zwolnienia ziemianina ze wszystkich świadczeń na rzecz króla czeskiego, za zasługi w służbie królewskiej. Wyjątkowy był też dokument dotyczący wizji lokalnej połączonej z przesłuchaniem świadków, w sporze stron o przebieg granicy lasu. Regułą zatem była jurysdykcja niesporna i tylko wyjątkowo sporna. Wszystkie te dokumenty były wystawiane w asyście świadków, którymi byli asesorowie wrocławskiego sądu dworskiego, zwani też ławnikami ziemi wrocławskiej. Starostę od czasu do czasu zastępował w tym gremium jeden z nich, najczęściej burgrabia z Urazu.

Właściwość terytorialna urzędu starościńskiego obejmowała całe ówczesne Księstwo Wrocławskie zwane też ziemią wrocławską. Jak daleko sięgały granice tego terytorium, nie wynika z umowy Jana Luksemburskiego z Henrykiem VI Dobrym z 6 kwietnia 1327 r. W wydanym w tym samym dniu przez tegoż króla przywileju dla jego mieszkańców i stanów zostali wymienieni obok mieszczan wrocławskich tylko mieszczanie średzcy (cives Noviforenses). Nasuwa się pytanie, czy ta widoczna niedookreśloność obszaru tego księstwa była przypadkowa, czy też wiązała się z dalekosiężnym planem króla czeskiego poszerzania jego granic o inne księstwa śląskie oraz terytoria wielkopolskie, małopolskie i mazowieckie. $Z$ dokumentu tego wynika, że były w nim tylko dwa znaczące ośrodki miejskie: Wrocław i Środa Śląska, z odrębnymi już weichbildami, wrocławskim położonym na prawym i lewym brzegu Odry i średzkim usytuowanym tylko na lewym brzegu. Ten obszar trzeba jednak powiększyć o Uraz, położony na prawym brzegu Odry na północny zachód od Wrocławia, który, będąc początkowo ośrodkiem okręgu grodowego z własnym kasztelanem (burgrabią), stał się okręgiem weichbildowym z zamkiem, miasteczkiem i sądem dworskim ${ }^{21}$. $\mathrm{Z}$ dokumentu z 28 lutego $1336 \mathrm{r}$. wynika ponadto, że w skład księstwa wchodziły nadal Prusice z okolicznymi miejscowościami (położone na północ od weichbildu urazkiego), podlegające jurysdykcji starosty wrocławskiego ${ }^{22}$. W dokumencie z 7 lutego 1340 r. Prusice wymienia się już wśród posiadłości księcia oleśnickiego Konrada (in Prusnicz opido districtus Trebniczensis) ${ }^{23}$. Zatem wróciły do Konrada przed tą datą, być może nawet $\mathrm{w}$ roku poprzednim. W kolejnym dokumencie z 13 marca 1344 r. Prusice są już odrębnym dystryktem usytuo-

${ }^{20}$ J. Kopietz: Die böhmische Landeshauptmanschaft in Breslau unter dem Könige Johann und dem Kaiser Karl IV. Breslau 1907.

${ }^{21} 1.03 .1328,30.04 .1320,9.01 .1337$ (RS 4726, 4942, 5807).

${ }^{22}$ GM II, s. 23-24, nr 19. Zob. RS 5577.

${ }^{23}$ GM II, s. 28, nr 25. 
wanym między dystryktami, trzebnickim i żmigrodzkim (in opido et districtu Prusniczensi inter Trebniciam et Trachinburk situatis $)^{24}$.

W dniu 27 stycznia 1336 r. zebrała się we Wrocławiu również kapituła generalna, na której dokonano uwierzytelnienia dwóch niebudzących podejrzeń i opieczętowanych dokumentów, z których pierwszy został spisany w języku niemieckim, natomiast drugi $\mathrm{w}$ łacińskim ${ }^{25}$. Zostały one przedłożone przez Konrada oleśnickiego, który zapewne gościł w tym czasie we Wrocławiu. Oba zostały wystawione Konradowi przez Jana Luksemburskiego we Wrocławiu w dniu 9 maja i w Zgorzelcu 19 maja 1329 r. Pierwszy był dokumentem lennego nadania Księstwa Oleśnickiego, natomiast drugi dotyczył przyrzeczenia złożonego przez nowego seniora Konradowi w sprawie odzyskania Prusic wraz z otaczającymi je wsiami, które od roku 1322 znajdowały się w posiadaniu księcia Henryka VI. Jego bezpotomna śmierć i przejęcie bezpośredniej władzy w Księstwie Wrocławskim przez króla skłoniła Konrada do udokumentowania swojego, ciągle niezaspokojonego, roszczenia i skłonienia króla do spełnienia solennego zobowiązania. Być może właśnie „kwestia prusicka” stała się powodem, choć zapewne nie jedynym, wydania przez Konrada dwa lata później (11 lutego 1338 r.) dokumentu, w którym sformułował pogląd o zwierzchnictwie papiestwa (a nie jakiegokolwiek króla czy cesarza) nad książętami śląskimi, wynikającym $\mathrm{z}$ uiszczania świętopietrza.

Nie wiadomo, na ile śmierć ostatniego Piasta wrocławskiego wywarła wpływ na poczynania niesfornego Jana ścinawskiego, którego w tym samym okresie spotykamy w Pradze. Tu, tytułując się tylko „księciem Śląska i panem Ścinawy”, 29 stycznia wystawił dokument, „za uprzednią radą swoich wiernych”, czyli zapewne na sejmiku Księstwa Ścinawskiego, w którym przekazał swoje prawo własności do księstwa i ziemi ścinawskiej (ducatum nostrum seu terram) oraz miast: Ścinawy (Stynavia), Góry (Gora), Lubina (Lubyn) i Wschowy (Wrawnstat) z zamkami i twierdzami oraz wszelkimi przynależnościami Janowi Luksemburskiemu ${ }^{26}$. Jako formę rekompensaty za tę swoistą darowiznę dokument przewidywał nadanie mu przez króla czeskiego miasta i ziemi głogowskiej (civitatem et terram suam Glogovie), do której aspirowali też jego żyjący bracia. Miało ono jednak tylko charakter czasowy, a ściślej dożywotni, i ograniczający jego ustrojowo-prawną pozycję do roli gubernatora i namiestnika (tamquam domino gubernatori et locum ipsius tenenti). Dokument ten trafił do archiwum, które później Karol IV usytuował na zamku Karlstein, i został włączony do działu $\mathrm{z}$ dokumentami książąt polskich (Ponatur ad homagia Polonorum). Zwraca uwagę fakt, że został on uwierzytelniony małą pieczęcią księcia $\mathrm{z}$ orłem i napisem: S. JOHIS DUC. SLE. GLOG. DNI ${ }^{27}$. W tej legendzie książę tytułuje się tylko

\footnotetext{
${ }^{24}$ GM II, s. 30, $\mathrm{nr} 30$.

${ }^{25}$ RS 5556; APWr., Rep. 132 c: Depozyt archiwum Księstwa Oleśnickiego.

${ }^{26}$ RS 5557; GM I, s. 139-141, nr 17.

${ }^{27} \mathrm{~W}$ dokumencie z 27 marca 1336 r. użył tej samej pieczęci. Zob. RS 5605.
} 
panem Głogowa. Tymczasem do tej pory książę tytułował się w zachowanych dokumentach wyłącznie panem Ścinawy, a w 1329 r. także dziedzicem Królestwa Polskiego. Natomiast w kolejnych dwóch dokumentach z 1336 r. tytułował się panem Głogowa i Ścinawy (25 listopada) oraz tylko panem Głogowa (4 grudnia) ${ }^{28}$. Zaskoczenie budzi fakt, że wkrótce po ich wystawieniu, 4 stycznia 1337 r., inny książę śląski, mianowicie Henryk jaworski, tytułuje się panem Głogowa i oznajmia o nadaniu mu dożywotnio przez króla czeskiego Głogowa z całym dystryktem i w związku z tym zobowiązał się on przestrzegać praw i wolności mieszkańców tego terytorium ${ }^{29}$. Odtąd Jan ścinawski tytułuje się ponownie tylko panem Ścinawy. W formule świadków (10) tego dokumentu pojawili się, poza wymienionymi na czele listy biskupem miśnieńskim i księciem saskim, co ciekawe, ziemianie wrocławscy (w tym kolejny z Borsniczów, Cunad) i trzech mieszczan wrocławskich. Książę zobowiązał się ponadto pod przysięgą, że ani potajemnie, ani oficjalnie nie będzie swojego rozporządzenia odwoływał albo podważał z powołaniem się na papieskie, cesarskie i królów rzymskich dokumenty, przywileje, indulgencje oraz prawo kanoniczne lub rzymskie. Ponadto zobowiązał się do zwolnienia swoich poddanych z Księstwa Ścinawskiego ze złożonego mu hołdu i przysięgi wierności oraz nakazania ponownego ich złożenia królowi i jego sukcesorom jako naturalnym dziedzicznym panom.

W ścisłym związku z tym dokumentem pozostaje następny, wydany w Głogowie przez Jana jako pana Głogowa i Ścinawy 25 listopada 1336 r. $^{30}$. Biorąc pod uwagę jego treść, wydaje się, że nastąpiło to na sejmiku ziemskim. Miasto Głogów, w zamian za liczne wyświadczone mu przysługi, uzyskało w nim prawo do pozywania w sprawach o długi każdego ziemianina rycerskiej kondycji (terrigenam conditionis militaris) z wymienionych dystryktów Księstwa Ścinawskiego: ścinawskiego, górowskiego, polkowickiego i nowomiejskiego, jeśli książę ze swoim dworem i służbą ulokuje się w tym mieście. Pozwani mieli stawać przed nim albo przed jego sędziami względnie sądami według następującej zasady: Polacy przed polskim sądem, natomiast Niemcy przed sądem dworskim. Przy czym każdy z wymienionych dystryktów według takiego samego prawa jak rycerze albo „osoby na miarę rycerską" z dystryktu głogowskiego $\mathrm{w}$ takich samych sprawach prawnych z mieszczanami głogowskimi. Na liście świadków znalazło się trzech rycerzy i dwóch mieszczan, którzy zapewne byli reprezentantami rycerstwa głogowskiego i mieszczan stołecznego Głogowa.

${ }^{28}$ RS 5753, 5759.

29 RS 5789; GM I, s. 143-144, nr 20.

${ }^{30}$ RS 5753; Archiwum Państwowe w Zielonej Górze, Akta miasta Głogowa, dokumenty (z zachowanymi resztkami książęcej pieczęci). Zawierający sporo błędów przedruk zamieścił w swojej pracy F. Minsberg: Geschichte der Stadt und Festung Groß-Glogau. Bd. 1: Mit einem Urkundenbuch. Glogau 1853, s. 355-356, natomiast fragmenty K. Wutke: Die Inventare der nichtstaatlichen Archive Schlesuens. II. Kreis und Stadt Glogau. Namens des Vereins für Geschichte Schlesiens. In: CDS, Vol. 28. Hrsg. K. Wutke. Breslau 1915, s. 21, nr 64. 
Przywilejem tym książę Jan chciał sobie niewątpliwie zjednać głównie miasto, ale i miejscową szlachtę przed planowanym przeniesieniem się wraz z dworem do Głogowa. Zwraca uwagę wymienienie tylko tych czterech dystryktów Księstwa Ścinawskiego, co zapewne oznacza, że pozostałe były obciążone prawami innych osób. Szczególnie interesująca jest dychotomia wymienionych tu sądów (polskie na pierwszym miejscu i niemieckie na drugim) oraz ich właściwość terytorialna w sprawach o długi mieszczan głogowskich, przekraczająca zasięg dystryktu głogowskiego. Uległa ona znacznemu powiększeniu o wymienione cztery dystrykty, w których też takie sądy istniały (sąd prawa polskiego bez wątpienia w Górze). W ten sposób właściwość terytorialna obu sądów głogowskich obejmowała też dystrykty wchodzące w skład odrębnego Księstwa Ścinawskiego, które miało trafić w ręce króla czeskiego. Sąd prawa polskiego w Głogowie i Górze funkcjonował aż do 1742 r.

Jako pan Głogowa i w odniesieniu do Księstwa Głogowskiego wystawił książę Jan jeszcze jeden dokument w dniu 4 grudnia 1336 r., w Przedmościu (Prsedemost) koło Głogowa ${ }^{31}$. Dotyczył on konfirmacji przewłaszczenia posiadłości w dystrykcie głogowskim na rzecz klasztoru w Przemęcie. Jego znaczenie podkreśla fakt, że został on 12 stycznia $1337 \mathrm{r}$. potwierdzony przez samego króla czeskiego na zjeździe we Wrocławiu ${ }^{32}$.

Dokumenty te dowodzą, że król czeski akceptował poczynania Jana ścinawskiego w okrojonym Księstwie Głogowskim nieomal do końca 1336 r. Na zmianę jego stanowiska $\mathrm{w}$ niespełna miesiąc później mogły wpływać protesty jego braci oraz królewski plan przejęcia Zgorzelca z rąk Henryka jaworskiego.

Najważniejszym wydarzeniem politycznym z perspektywy przemian ustrojowych Śląska było uznanie zwierzchnictwa lennego króla czeskiego przez dotychczas wolnego księcia z linii świdnickiej i skutecznie opierającego się do tej pory jego naciskom, także militarnym, mianowicie Bolka ziębickiego. Poświadcza je łacińskojęzyczny dokument wystawiony przez księcia w dniu 29 sierpnia $1336 \mathrm{r}$. w miejscowości Straubing (Strubinge), położonej w Dolnej Bawarii na prawym brzegu Dunaju ${ }^{33}$. W miejscowości tej przebywał król czeski w związku z wyprawą bawarską przeciw Wittelsbachom. Podkreślono w nim, że decyzja książęca została podjęta po naradzie $\mathrm{z}$ radcami, wasalami i konsulami miast księstwa i ziem do niego przynależnych oraz wymienionych z nazwy miast (civitates): Ziębice (Munsterberch), Dzierżoniów (Reichenbach), Ząbkowice (Frankenstein), Strzelin (Strzelin), Kąty (Kant), Sobótka (Sobotka), miasteczko Sobótka (opidum Sobotka) i zamek Paczków (castrum Paczkow). Dwukrotne wymienienie Sobótki sugeruje występowanie dwóch ośrodków miejskich, starszego (opidum) na prawie polskim i młodszego lokowanego na prawie niemieckim. Oczywiście

\footnotetext{
${ }^{31}$ RS 5759; Codex Diplomaticus Maioris Poloniae. T. 2. Poznań 1878, s. 490—491.

${ }^{32}$ RS 5812.

${ }^{33}$ RS 5692; GM II, s. 128-130, nr 2. Oryginał w Archiwum Państwowym w Pradze.
} 
Sobótka funkcjonowała jako ośrodek odrębnego dystryktu ziemskiego, podobnie jak pozostałe miasta. Zastanawiająca jest natomiast pozycja ustrojowo-prawna Paczkowa nazwanego tutaj tylko zamkiem, co z kolei sugeruje jego rolę jako ośrodka niewielkiego okręgu zamkowego (grodowego) a nie miejskiego jak $\mathrm{w}$ przypadku poprzedzających go w wyliczeniu ośrodków miejskich ${ }^{34}$.

Nie była to zatem arbitralna decyzja samego księcia, lecz uwzględniająca radę, wolę, przyzwolenie i zgodę politycznie czynnych stanów księstwa. Przedstawicieli wasali wymieniono imiennie, natomiast miast nie, ale podkreślono, że występują w imieniu własnym oraz swoich wspólnot (communitas), czyli korporacji ziemskich i miejskich Księstwa Ziębickiego. Znalazło się wśród nich sześciu wasali Bolka ziębickiego oraz konsulowie pięciu wymienionych miast, zapewne po jednym z każdego miasta. W reprezentacji miast zwraca uwagę brak Sobótki i Paczkowa, natomiast w składzie całego tego stanowego wydziału — ilościowa równowaga między wasalami i miastami. Pełnili oni rolę gwarantów zawartego kontraktu lennego, których nie spotyka się we wcześniejszych dokumentach lennych książąt śląskich.

Dodatkową gwarancją było złożone uroczyście, przez dotknięcie przenajświętszej ewangelii, przyrzeczenie księcia w imieniu własnym oraz swoich wasali i miast, że nie będzie w przyszłości występował z zarzutami lub roszczeniami - zarówno o charakterze prawnym, jak i faktycznym - przeciwko postanowieniom tego dokumentu. Zobowiązał się równocześnie do niewykorzystywania w tym celu prawa kanonicznego, cesarskiego, cywilnego, municypalnego, reformacyjnego oraz lokalnych statutów lub zwyczajów. Zwraca uwagę pominięcie w tym wyliczeniu prawa lennego i polskiego.

Dokument został uwierzytelniony dwunastoma pieczęciami: pieczęcią konną Bolka ziębickiego, sześcioma osobistymi pieczęciami wasali oraz pięcioma pieczęciami korporacyjnymi miast. W legendzie tych ostatnich najczęściej podkreślano, że pieczęć określonego nazwą miasta jest pieczęcią mieszczan (civium), natomiast rzadziej (jak w wypadku miasta Strzelin), że miasta (civitatis $^{35}$. Zaskakuje przy tym brak drugiego dokumentu lennego wystawionego przez króla czeskiego. Może taki dokument został w tym roku wystawiony, ale zaginął albo monarcha $\mathrm{z}$ tym zwlekał.

Relacja księcia do króla czeskiego, ale także do Królestwa Czech, utożsamianego z Koroną, miała charakter perpetualny, czyli wieczysty. Księcia i jego sukcesorów zaliczono do lenników, czyli feudałów Królestwa Czech (feodales

${ }^{34}$ M.J. Ptak: Paczków i weichbild paczkowski w ustroju politycznym Księstwa Nyskiego. W: O prawie i jego dziejach księgi dwie. Studia ofiarowane profesorowi Adamowi Lityńskie$m u$ czterdziestolecie pracy naukowej i siedemdziesięciolecie urodzin. Ks. 1. Białystok 2010, s. $193-198$.

${ }^{35}$ W sprawie tych pieczęci miejskich zob. O. Hupp: Die Wappen und Siegel der deutschen Städte, Flecken und Dörfer: 1, 2: Königreich Preußen. 2. Heft: Pommern, Posen und Schlesien. Frankfurt am Main 1898. 
regni Bohemie) i nie nazywano wasalami. Wasalami nazwano tylko poddanych ziemian Księstwa Ziębickiego. Jan Luksemburski występuje w tym dokumencie jako princeps, rex, comes, dominus i ani razu jako senior. Nadal konsekwentnie nie używano wobec niego tytułu księcia Głogowa, Wrocławia i Śląska. Uwagę zwraca tytulatura Bolka, który w omawianym dokumencie tytułuje się ,z łaski Bożej księciem (dux) Śląska i panem (dominus) w Ziębicach”. Dzielnica ziębicka została mu wyznaczona w 1315 r., ale samodzielne rządy objął w niej dopiero w 1322 r. Było to zatem księstwo stosunkowo nowe, wcześniej nieistniejące. W 1335 r. książę tytułował się wyjątkowo „księciem Książa (Furstinberg)”, ale najczęściej „panem Książa”36. „Panem Książa i Ziębic” tytułował się jeszcze na początku 1337 r., a w legendzie swojej pieczęci nawet tylko „panem Książa” z pominięciem „Ziębic" ${ }^{37}$. Książ podkreślał pochodzenie tej linii książąt śląskich.

Omawiany dokument dostarcza interesującej informacji o formie zawarcia kontraktu lennego, której nie znajdujemy we wcześniejszych dokumentach lennych książąt śląskich. Pierwszym aktem była wymiana pocałunku między królem i księciem ( per osculum), natomiast kolejnym przeniesienie nakrycia głowy księcia, nazwanego tu biretem (birretum), do rąk króla i następnie ponowne jego przyjęcie przez księcia. Chodzi tu o okrągłe nakrycie głowy przysługujące, według ówczesnego ceremoniału dworskiego, wyłącznie książętom zwane biretem książęcym (biretum ducale). Jest to zatem przykład inwestytury per biretum, która wizualizowała i symbolizowała dwie czynności prawne, przeniesienie własności księstwa na króla pod warunkiem natychmiastowego zwrotnego przeniesienia tej własności uprzednio pełnemu właścicielowi, który nie był odtąd właścicielem alodialnym, lecz lennym, czyli podległym (ograniczonym) według koncepcji własności podzielonej. Powstało w ten sposób lenno nadane (feudum oblatum), jak wszystkie dotychczasowe lenna książęce na Śląsku, które książę przyjął jako lenno honorowe (in feodum honorabile recipimus).

Książę godził się na znaczne ograniczenie praw swoich sukcesorów. Dokument przewidywał bowiem tylko dziedziczenie księstwa przez jego synów i to pod warunkiem, że będą uznawać zwierzchnictwo lenne króla Czech. W tym czasie miał Bolko tylko jednego syna, Mikołaja (1322/1327-1358), co dawało królowi realną nadzieję na przejęcie księstwa prawem lennego kaduka i uczynienia zeń kolejnego księstwa dziedzicznego Korony Czeskiej. Był ponadto ojcem jednej córki (klaryska strzelińska Małgorzata 1322/1330-1368) albo dwóch córek (wątpliwej i nieznanej z imienia żony Siemowita mazowieckiego). Praw spadkowych został całkowicie pozbawiony starszy brat Bolka, Henryk jaworski (1292/1296-1346) oraz synowie jego najstarszego brata Bernarda świdnickiego (zm. 1326), Bolko II Mały świdnicki (1309/1312-1368) i Henryk świdnicki (1316/1324-1343/1345). Najbliższym męskim krewnym i spad-

\footnotetext{
${ }^{36} \mathrm{RS} 5435,5438$.

37 GM I, s. $488-489$, nr 3.
} 
kobiercą w przypadku bezpotomnej śmierci Bolka ziębickiego byłby zatem Henryk jaworski i dopiero w drugiej kolejności jego dwaj bratankowie, jeśli obowiązywała zasada reprezentacji (ius repraesentationis). Wykluczono zatem w tym momencie trzech męskich spadkobierców w linii bocznej, którzy zmarli bezpotomnie w następnych latach, w ciągu najbliższej dekady Henryk świdnicki i Henryk jaworski, a u schyłku lat sześćdziesiątych Bolko świdnicko-jaworski. Luksemburgowie osłabili $\mathrm{w}$ ten sposób linię książąt świdnickich i stworzyli wyłom w ich dotychczasowym statusie wolnych i dziedzicznych książąt. Tego ich statusu w żaden sposób nie bronił Kazimierz zwany Wielkim, wywodzący się przecież z tej samej dynastii, a odkładanie przez niego sprawy śląskiej na później okazało się fatalne w skutkach.

W razie śmierci Bolka bez męskiego potomka jego księstwo miało przypaść wieczyście Królestwu Czech i jej Koronie (regnum Boemie et coronam). Jeszcze bardziej niekorzystnie zostało uregulowane prawo do opieki i kurateli. Wykluczono zupełnie najbliższych krewnych i powinowatych księcia, a wyłączne prawo wobec jego niepełnoletnich dzieci uzyskiwał król Czech (rex Boemie eorum tutor erit legitimus et curator). Nawiązano tu zatem do występującej w prawie polskim instytucji rządów opiekuńczych (tutorat) i kuratorskich (kuratorat), sprawowanych przez najbliższych krewnych ${ }^{38}$. Na mocy tego prawa Bolko ziębicki do 1321 r. pozostawał pod opieką swojego najstarszego brata, Bernarda świdnickiego. Według tego prawa powinien je sprawować Henryk jaworski, ale król przypisał je sobie jako lennemu zwierzchnikowi na podstawie prawa lennego.

Wśród motywów skłaniających Bolka ziębickiego do uznania zwierzchnictwa lennego króla czeskiego trzeba wziąć pod uwage jego zadłużenie, pogłębione przez wydatki na zwycięską wojnę obronną przeciw najazdowi na księstwo wojsk czeskich w 1335 r. Choć cieszył się w niej poparciem miast, zwłaszcza Ząbkowic, oraz przynajmniej części miejscowej szlachty, to jednak ujawnił się brak wsparcia ze strony książąt linii świdnickiej i pozostałych książąt śląskich oraz króla polskiego. Stosunki osobiste z książętami linii świdnicko-jaworskiej nie były najlepsze, skoro nie widać w tej grupie książąt skłonności do współdziałania, jak w przypadku książąt legnicko-brzeskich, w celu stworzenia kompleksu terytorialnego pospólnej ręki. W związku z tym chciał być może poprawić swoją sytuację wobec brata i bratanków, którzy nie byli nadal lennikami króla czeskiego. Jego pozycję osłabiał ponadto konflikt z Kościołem. Jeszcze w lutym 1336 r. skarżył się ówczesnemu nuncjuszowi papieskiemu na ekskomunikę i interdykt, nałożone na niego i całe księstwo, za których zniesienie poprzedni nuncjusz wymusił na nim kwotę 150 marek $^{39}$. Przynętą dla Bolka było niewątpliwie Kłodzko, opróżnione po śmierci księcia wrocławskiego, na które w pertrakta-

38 W. Sobociński: Historia rzadów opiekuńczych w Polsce. „Czasopismo Prawno-Historyczne" 1949 , T. 2, s. 227-353.

${ }^{39}$ RS 5567, 5568; Vetera monumenta Poloniae et Lithuaniae... ex tabulis Vaticanis. Ed. A. Theiner. Vol. 1. Roma 1861, s. 375 i nast. 
cjach z królem czeskim mógł liczyć. Jest prawdopodobne, że wstępne rozmowy w tej sprawie odbyły się już po nieudanym oblężeniu Ząbkowic przez Karola i rycerskim postępku Bolka wobec ujętych jeńców ${ }^{40}$. Według C. Grünhagena padło wówczas przyrzeczenie uznania zwierzchnictwa króla, a jako gwarancja albo zabezpieczenie udzielonej pożyczki został ustanowiony zastaw króla na zamku w Kątach, który on opanował już na początku wojny z Bolkiem ${ }^{41}$. Dla króla czeskiego Księstwo Ziębickie miało strategiczne znaczenie, sąsiadowało bowiem od południa z ziemią kłodzką, od zachodu z Księstwem Świdnickim a od północy, co szczególnie istotne, z Księstwem Wrocławskim. Był to szlak prowadzący z Czech do Wrocławia i dalej do Głogowa oraz Wielkopolski.

Równie doniosłym wydarzeniem politycznym, jak rok wcześniej w odniesieniu do Księstwa Wrocławskiego, była bezpotomna (przypuszczalnie w pierwszej połowie 1336 r.) śmierć 46-letniego Leszka raciborskiego ${ }^{42}$. Księstwo Raciborskie zwane też ziemią raciborską, w świetle dokumentu lennego z 10 lutego 1327 r., w którym tytułował się tylko księciem raciborskim (Lesko dux Ratiboriensis) bez odniesienia do Śląska, obejmowało: miasto z zamkiem Racibórz (Ratibor, Ratbor), miasta Koźle (Cosla), Żory (Sor), Pszczyna (Plesna), Gliwice (Klewicz) oraz zamek z miasteczkiem (oppido) Rybnik (Ribinek) ${ }^{43}$. Były to ośrodki ówczesnych dystryktów ziemskich. Z niektórych z nich w późniejszym czasie wyodrębnią się jeszcze kolejne dystrykty (Wodzisław, Mikołów) ${ }^{44}$. Tworzyły więc spory kompleks terytorialny, do którego prawa spadkowe na podstawie książęcego prawa polskiego przysługiwały potomkom zmarłego w $1281 \mathrm{r}$. księcia opolsko-raciborskiego Władysława. $Z$ roszczeniami do tego terytorium wystąpił jednak również książę opawski z dynastii Przemyślidów Mikołaj II, będący mężem siostry Leszka raciborskiego, Anny. Stało się to zarzewiem ostrego konfliktu prawnego, który zostanie rozstrzygnięty dopiero w następnym roku.

\section{$* * *$}

W 1327 r. został zapoczątkowany przez Jana Luksemburskiego, tytułującego się w tym czasie królem Czech i - co zapewne nie było bez znaczenia - także Polski, proces feudalizacji księstw śląskich. Do 1336 r. nie objął on książąt linii świdnicko-jaworskiej. Zhołdowanie w tym roku księcia ziębickiego stanowi w tym procesie ważną cezurę. Był to również rok, w którym urzeczywistnił się sformalizowany w 1327 r. polityczny plan Jana Luksemburskiego przejęcia

${ }^{40}$ Chronica principum Poloniae. In: Scriptores Rerum Silesiacarum. Hrsg. G.A. Stenzel. Bd. 1. Breslau 1835, s. 123-124.

${ }^{41}$ Geschichte Schlesiens. Erster Band: Bis zum Eintritt der Habsburgischen Herrschft 1527. Gotha 1884, s. 147.

${ }^{42}$ K. Jasiński: Rodowód Piastów... T. 3, s. 59-60; J. Horwat: Książęta górnoślascy z dynastii Piastów. Uwagi i uzupetnienia genealogiczne. Ruda Śląska 2005, s. 122-126.

${ }^{43}$ GM II, s. 379-386, nr 1.

${ }_{44} 9.07 .1339,30.01 .1366,14.06 .1375$ (GM II, s. 385-389, nr 4, 6, 8). 
bezpośredniego panowania w Księstwie Wrocławskim. Oznaczało to kres rządów przyrodzonych książąt tej linii i początek rządów w tym księstwie królów czeskich, realizowanych za pośrednictwem monokratycznego starostwa ziemskiego o charakterze namiestniczym. Księstwo Wrocławskie będzie odtąd nieprzerwanie aż do 1742 r. dziedzicznym księstwem korony czeskiej. W 1336 r. Jan ścinawski zrzekł się wszelkich praw do swojego lennego Księstwa Ścinawskiego na rzecz króla czeskiego, w zamian za dożywotnie rządy namiestnicze w Księstwie Głogowskim. Przypomina to zmodyfikowany wariant wrocławski z 1327 r. Nie doczekał się on jednak pełnej realizacji z powodu zmiany politycznych planów Jana Luksemburskiego w następnym roku. Odroczone zostały również skutki prawne i polityczne bezpotomnej śmierci Leszka raciborskiego, niezaliczanego do książąt śląskich lecz opolskich. W kontekście wydarzeń 1336 r. zastanawia mało aktywna polityka śląska króla polskiego Kazimierza zwanego Wielkim w odpowiedzi na politykę faktów dokonanych uprawianą przez Jana Luksemburskiego, naruszającą postanowienia wyszehradzkie z 1335 r. Wydaje się, że nie do końca tłumaczy ją zagrożenie ze strony zakonu krzyżackiego oraz obawa przed jego sojuszem z królem czeskim. W bilansie korzyści i strat politycznych coraz większe znaczenie zyskiwała niestety polityka wschodnia wobec ziem ruskich.

\section{Bibliografia}

\section{Źródla}

Archiwum Państwowe we Wrocławiu, Rep. 58: Klasztor Dominikanek św. Katarzyny we Wrocławiu, Rep. 132 c: Depozyt archiwum Księstwa Oleśnickiego.

Archiwum Państwowe w Zielonej Górze, Akta miasta Głogowa, Dokumenty.

Chronica principum Poloniae. In: Scriptores rerum Silesiacarum oder Sammlung schlesischer Geschichtsschreiber. Hrsg. G.A. Stenzel. Bd. 1. Breslau 1835.

Codex Diplomaticus Maioris Poloniae. Vol. 2. Poznań 1878.

Die Inventare der nichtstaatlichen Archive Schlesiens. II. Kreis und Stadt Gross-Glogau. In: Codex Diplomaticus Silesiae. Vol. 28. Hrsg. K. Wutke. Breslau 1915.

Henricus Pauper. Rechnungen der Stadt Breslau von 1299-1358, nebst zwei Rationarien von 1385 und 1387, dem Liber Imperatoris vom Jahre 1377 und den ältesten Breslauer Statuten. In: Codex Diplomaticus Silesiae. Vol. 3. Hrsg. C. Grünhagen. Breslau 1860.

Lehns=und Besiturkunden Schlesiens und seiner einzelnen Fürstenthümer im Mittelalter. Hrsg. C. Grünhagen, H. Markgraf. Teil 1-2. Leipzig 1881-1883.

Regesten zur schlesischen Geschichte. 1327-1333. In: Codex Diplomaticus Silesiae. Vol. 23. Hrsg. C. Grünhagen, K. Wutke. Breslau 1903. 
Regesten zur schlesischen Geschichte. 1334-1337. In: Codex Diplomaticus Silesiae. Vol. 29. Hrsg. K. Wutke. Breslau 1923.

Urkunden des Klosters Kamenz. In: Codex Diplomaticus Silesiae. Vol. 10. Hrsg. P. P fotenhauer. Breslau 1881.

Vetera monumenta Poloniae et Lithuaniae... ex tabulis Vaticanis. Ed. A. Theiner. Vol. 1-4. Roma 1861-1864.

\section{Literatura}

Bobertag G.: Die Gerichte und Gerichtsbücher des Fürstenthums Breslau. „Zeitschrift des Vereins für Geschichte und Alterthum Schlesiens" 1866, Bd. 7, H. 2.

Dąbrowski J.: Dzieje polityczne Ślaska w latach 1290-1402. W: Historia Ślaska od najdawniejszych czasów do roku 1400. Red. S. Kutrzeba. Kraków 1933.

Geschichte Schlesiens. Erster Band: Bis zum Eintritt der Habsburgischen Herrschft 1527. Gotha 1884.

Grünhagen C.: Geschichte Schlesiens. Bd. 1: Bis zum Eintritt der habsburgischen Herrschaft 1527. Gotha 1884.

Historia Śląska. T. 1: Do roku 1763. Cz. 1: Do połowy XIV w. Red. K. Maleczyński. Wrocław 1960.

Horwat J.: Ksiązęta górnośląscy z dynastii Piastów. Uwagi i uzupetnienia genealogiczne. Ruda Śląska 2005.

Hupp O.: Die Wappen und Siegel der deutschen Städte, Flecken und Dörfer. 1, 2: Königreich Preußen. 2. Heft: Pommern, Posen und Schlesien. Frankfurt am Main 1898.

Jasiński K.: Rodowód Piastów śląskich. T. 1-3. Wrocław 1973-1977.

Jurek T.: Obce rycerstwo na Śląsku do połowy XIV wieku. Poznań 1998.

Kopietz J.: Die böhmische Landeshauptmanschaft in Breslau unter dem Könige Johann und dem Kaiser Karl IV. Breslau 1907.

Minsberg F.: Geschichte der Stadt und Festung Groß-Glogau. Bd. 1: Mit einem Urkundenbuch. Glogau 1853.

Ptak M.J.: Paczków i weichbild paczkowski w ustroju politycznym Księstwa Nyskiego. W: O prawie i jego dziejach księgi dwie. Studia ofiarowane profesorowi Adamowi Lityńskiemu $w$ czterdziestolecie pracy naukowej i siedemdziesięciolecie urodzin. Ks. 1. Białystok 2010.

Sobociński W.: Historia rządów opiekuńczych w Polsce. „Czasopismo Prawno-Historyczne" 1949, T. 2.

Wendt H.: Das Siegel der kgl. Landeshauptmanschaft im Fürstenthum Breslau. „Zeitschrift des Vereins für Geschichte und Alterthum Schlesiens” 1899, Bd. 33. 
Marian J. Ptak

\section{Das Jahr 1336 im Prozess des politisch-rechtlichen Wandels in Schlesien}

Schlüsselwörter: Schlesien, System, Recht, $1336 \mathrm{Jahr}$

Zusammenfassung: Im Prozess des politischen und rechtlichen Wandels in Schlesien, der im Jahre 1327 begann, verdienen die Ereignisse von 1336 besondere Aufmerksamkeit. Das früheste Ereignis betrifft die Umwandlung des Herzogtums Breslau in das erbliche Fürstentum der böhmischen Krone, in dem das Statthalteramt vom Landrat im Namen des Königs von nun an bis 1742 bekleidet wurde. Das nächste Geschehnis betrifft die Feudalisierung des ersten der bisher noch freien Herzöge der Linie Świdnica-Jawor, Bolko Ziębicki. Das weitere Ereignis bezieht sich auf den Verzicht auf die Rechte auf das Herzogtum Steinau durch seinen bisherigen Lehnsherzog aus der schlesischen Piastendynastie, Johann von Steinau, zugunsten des böhmischen Königs Jan von Luxemburg, um das Statthalteramt im Herzogtum Glogau lebenslang auszuüben. Das nächste Ereignis steht im Zusammenhang mit dem nachkommenlosen Tod des oberschlesischen Herzogs Leszek von Ratibor im Jahr 1336, der 1337 zu einem spektakulären Rechtsstreit um das Erbrecht nach ihm führte. Diese Ereignisse bewegen dazu, die schlesische Politik von Jan von Luxemburg und Kasimir dem Großen nach dem Visegáder Kongress von 1335 zu bewerten.

Marian J. Ptak

\section{The year 1336 in the process of political and legal transformations in Silesia}

Keywords: Silesia, system, law, year 1336

Summary: In the process of political and legal transformations in Silesia, initiated in 1327, the events that took place in 1336 deserve more attention. The earliest one concerns the transformation of the Duchy of Wrocław into the hereditary Duchy of the Czech Crown, where the governor's rule on behalf of the king would be held from then on by the land starost until 1742 . The next one deals with the feudalisation of the first of the still free dukes of the ŚwidnickoJaworsk line, Bolko Ziębicki. The next one refers to the resignation of the rights to the Duchy of Ścinawa by its former liege duke from the Silesian Piast dynasty, Jan ścinawski, in favour of the Czech king, John of Bohemia, in exchange for lifetime governor's rule in the Duchy of Głogów. The next one is connected with the childless death of the Upper Silesian Duke Leszek of Racibórz in 1336, which in 1337 would be the cause of a spectacular dispute over the inheritance rights after him. These events provoke an attempt to evaluate the Silesian policy of John of Bohemia and Casimir the Great after the Visegrad Congress of 1335. 
